\title{
İLKOKULA HAZIRBULUNUŞLUK ÖLÇEĞİ: YAPISAL GÜÇLENDİRME ÇALIŞMASI
}

\begin{tabular}{|c|c|c|c|c|}
\hline Tuncay Can & & Halit Kırıktaş $^{2}$ & İbrahim Hakk1 Tezci3 & \\
\hline Makale Bilgisi & \multicolumn{4}{|c|}{ Özet } \\
\hline DOI: 10.35 & \multirow{10}{*}{\multicolumn{4}{|c|}{ 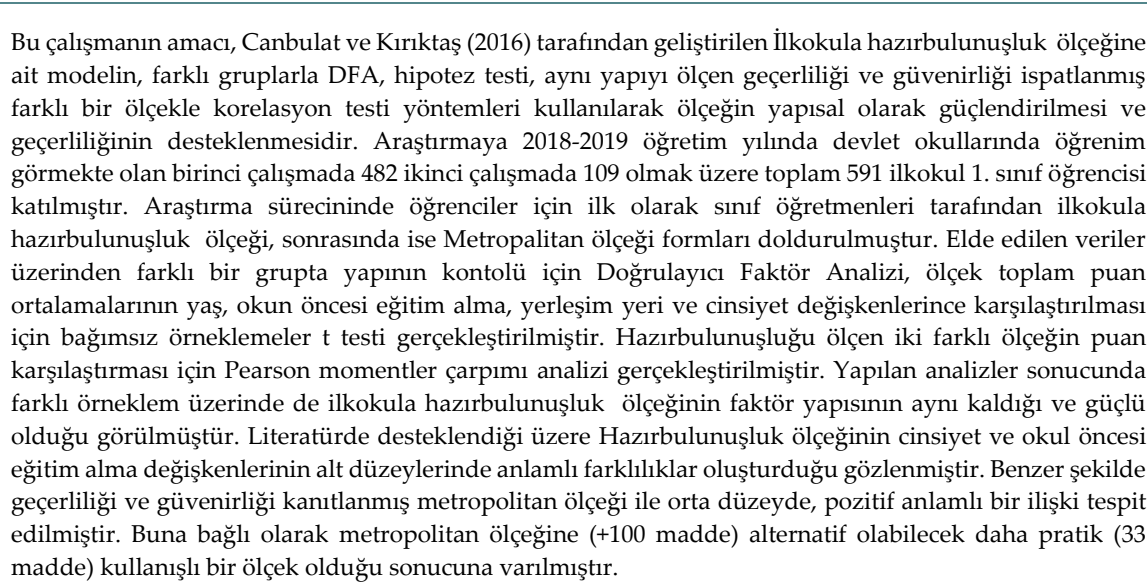 }} \\
\hline Anahtar Kelimeler & & & & \\
\hline & & & & \\
\hline çek Revizyonu & & & & \\
\hline & & & & \\
\hline itan & & & & \\
\hline Farklı Grup DFA & & & & \\
\hline & & & & \\
\hline & & & & \\
\hline Yayın Tarihi: 27.12 .2020 & & & & \\
\hline
\end{tabular}

\section{PRIMARY SCHOOL READINESS SCALE: STRUCTURAL STRENGTHENING} STUDY

\begin{tabular}{|c|c|}
\hline Article Info & Abstract \\
\hline DOI: 10.35452/caless.2020.36 & \multirow{11}{*}{$\begin{array}{l}\text { The purpose of this study is to strengthen the structure and support validity of the Primary School } \\
\text { Readiness Scale's current model developed by Canbulat and Kiriktas (2016) by performing a correlation } \\
\text { test with a scale which measures the same structure and is proven in terms of reliability and validity and } \\
\text { whose CFA and hypothesis test were computed with different groups. } 591 \text { first-grade primary school } \\
\text { students studying at public schools participated in the study. Out of } 482 \text { took part in the first study, of } 109 \\
\text { were in the second study. During the research process, the students first filled out the Primary School } \\
\text { Readiness Scale and then the Metropolitan Scale forms with the help of their classroom teachers. } \\
\text { Confirmatory Factor Analysis was used to control the structure in a different group, independent samples } \\
\text { t-test was used to compare the scale total score averages by age, pre-school education, place of residence, } \\
\text { and gender. Besides, Pearson product-moments correlation was performed to compare the scores of two } \\
\text { different scales measuring readiness. According to the results, it was found that the factor structure of the } \\
\text { Primary School Readiness Scale remained the same and was strong on different samples. As supported by } \\
\text { the literature, it was observed that the Primary School Readiness Scale created significant differences in the } \\
\text { sub-levels of gender and the case of attending pre-school education. Similarly, a moderate positive } \\
\text { relationship was found between the Primary School Readiness Scale and the metropolitan scale whose } \\
\text { validity and reliability were proven. Accordingly, it was concluded that it was a more practical scale ( } 33 \\
\text { items) that can be an alternative to the Metropolitan Scale (+100 items) }\end{array}$} \\
\hline Keywords & \\
\hline Readiness & \\
\hline Scale Revision & \\
\hline Primary School & \\
\hline Metropolitan & \\
\hline Different group CFA & \\
\hline Received: 19.11 .2020 & \\
\hline Accepted: 25.12 .2020 & \\
\hline & \\
\hline & \\
\hline
\end{tabular}

APA'ya göre alıntılama: Canbulat, T., Kırıktaş, H., Tezci, İ.H. ve İlhan, E. (2020). İlkokula hazırbulunuşluk ölçeği: Yapısal güçlendirme çalışması. Uluslararası Dil, Eğitim ve Sosyal Bilimlerde Güncel Yaklaşımlar Dergisi (CALESS), 2(2), 675-687.

Cited as APA: Canbulat, T., Kırıktaş, H., Tezci, İ.H., \& İlhan, E. (2020). Primary school readiness scale: structural strengthening study. International Journal of Current Approaches in Language, Education and Social Sciences (CALESS), 2(2), 675-687.

\footnotetext{
1 (D) Dokuz Eylül Üniversitesi, Eğitim Fakültesi, Türkiye, tuncaycanbulat@gmail.com

2 (D) Siirt Üniversitesi, Eğitim Fakültesi, Türkiye, halit.kiriktas@gmail.com

3 (iD) Akdeniz Üniversitesi, Eğitim Fakültesi, Türkiye, ihtezci@akdeniz.edu.tr

4 (D) Dokuz Eylül Üniversitesi, Eğitim Fakültesi, Türkiye, ilhanelif35@gmail.com
} 


\section{Giriş}

Bireylerde informal olarak aile ile başlayan eğitim süreci okul öncesi, ilkokul, ortaokul, lise ve lisans kademeleriyle örgün olarak gerçekleşirken informal olarak yaşam boyu devam eder. Her eğitim kademesinde birey birtakım yeterlilikler ve gelişimsel özellikler kazanarak bir sonraki eğitim sürecine geçer. Modüler yapı olarak adlandırılan bu süreçte birey her eğitim kademesinde bir takım beceri ve yeterlilikler kazanarak, sonraki eğitim sürecine başlar. Bu süreçte bireyin bulunduğu eğitim kademesinde amaçlanan beceri ve yeterlilikleri kazanması sonraki eğitim sürecinde başarılı olması için gerekli ve önemlidir (Alkan ve Teker, 1992).

İlk bebeklikten 60 aylık sürece kadar ailede gerçekleşen eğitim sürecinde bireyler temel yaşam becerileri (beslenme, temel öz bakım, konuşma vb.) kazanırlar. Okul öncesi dönem (60-72) ise bireylerin örgün öğretime hazırlık aşaması olarak yine temel becerilerin kazandırılmaya çalışıldığı bir dönem olarak görülebilir (Senemoğlu, 1994). İlkokul sürecinde ise bireyler ilk olarak okuma-yazma ve temel matematik alanındaki içerikleri yapılandırarak, ilk defa tek olarak sınıf iklime uyum sağlayarak sosyalleşirler. Bu süreçte söz konusu becerileri kazanabilmeleri ve toplum hayatına (sınıf iklimine) uyum sağlayabilmeleri ilkokul öncesi kazandıkları beceri ve yeterliliklere bağlı olduğu söylenebilir (Fidan ve Baykul, 1994). İlk okula hazırbulunuşluk kavramı ile ifade edilen bu yeterlilikler bilişsel, duyusal, psikomotor ve öz bakım becerileri olarak sınıflandırılabilir (Başaran, 1998; Binbaşığlu, 1995). Farklı bir ifadeyle ilkokula hazırbulunuşluk, bireyin ilkokul eğitimi için gerekli olan bilişsel, duyuşsal, psikomotor ve öz bakım becerilerine sahip olması olarak tanımlanabilir (Ülgen, 1997; Yılmaz ve Sünbül, 2003). Tanımlamadan yola çıkacak olursak bireylerin ilkokul eğitimine başlayabilmeleri ve bu süreçte başarı gösterebilmeleri için bilişsel olarak yeterli gelişimsel özelliklere sahip olmalıdır (Çataloluk, 1994). Yani bireyler işlem öncesi döneminin özellikleri olan sıralama, sınıflama, somut problem çözme gibi bilişsel becerilere sahip olmalıdır. Yine bireylerin duyuşsal olarak empati yapma bir gruba aidiyet gibi becerilere ulaşmış olmalıdır. Psikomotor olarak ise devinimsel koordinasyonu (kalem tutma gibi) sağlamış olmalıdırlar (Binbaşığlu, 1995). Son olarak bireylerin öz bakım olarak adlandırılan, kişisel temizlik, beslenme, giyim ve eşya düzeni gibi yeterliliklere ulaşmış olmaları gerekmektedir. Bu gereklilikler beraberinde bireylerin ilkokula başlangıçlarında gerekli hazırbulunuşluğa sahip olup olmadıkların belirlenmesinin kaçınılmaz hale getirmektedir.

$\mathrm{Bu}$ bağlamda alan yazın incelendiğinde bireylerin ilkokula hazırbulunuşluk düzeylerinin belirlenmesine yönelik birçok çalışmanın yapıldı̆̆ı görülmektedir. 2016 
yılına kadar yapılan çalışmalarda genellikle nitel bir yöntem öğretmen gözlemlerinin kullanıldığı görülmektedir (Fidan, vd., 2013; Işıkoğlu ve Ceren, 2014; Kapçı vd., 2013; Kerimoğlu, 2014; Ünver vd., 2015). Yapılan diğer çalışmalarda ise genellikle metropolitan gelişim testinin ve Marmara hazırbulunuşluk ölçeğinin kullanıldı̆̆ı göze çarpmaktadır (Akyol, 2015; Dereobalı, 2016; Karakuzu ve Koçyiğit, 2016; Uzun ve Alat, 2017). Bu iki ölçme aracının 100 maddeden daha fazla maddeye sahip olması ve birinin ücretli, diğerinin ise uyarlanmış ölçek olması ölçme araçlarının kullanışlılı̆̆ını olumsuz etkilemektedir. Diğer taraftan ölçme araçlarının öğretmen tarafından öğrenciler için doldurulacak olması madde sayısının fazla olmasına bağlı olarak kullanımının zorluğunu artırmaktadır.

$\mathrm{Bu}$ durumun oluşturduğu olumsuzluğu gidermek amaciyla Canbulat ve Kırıktaş (2016) tarafından geliştirilen İlkokula Hazırbulunuşluk Ölçeğinin 33 maddeden oluşan ulusal dilde hazırlanmış herkesin kullanımına açık bir ölçme aracıdır. Nitekim söz konusu ölçme aracının farklı çalışmalarda da kullanıldığı görülmektedir (Çökük ve Kozikoglu, 2020; Türkyılmaz ve Pekdoğan 2019). Yaygın olarak kullanılmaya başlanan ilkokula hazırbulunuşluk ölçeğinin yapısal yeterliliğinin güçlendirilmesi ve kullanılan diğer ölçeklerle ilişkisinin ortaya konması ölçme aracını yapısal yönden güçlendirmenin yanında söz konusu ölçme araçlarına bir alternatif olabileceğini ortaya koyacaktır.

Bu kapsam yürütülen çalışmada amaç; Canbulat ve Kırıktaş (2016) tarafından geliştirilen İlkokula hazırbulunuşluk ölçeğinin var olan modelinin, farklı gruplarla DFA, Hipotez testi, aynı yapıyı ölçen geçerliliği ve güvenirliği ispatlanmış farklı bir ölçekle korelasyon testi yapılarak yapısal olarak güçlendirilmesi ve geçerliliğinin desteklenmesidir.

Bu amaç doğrultusunda aşağıdaki sorulara cevap aranmıştır.

> İlkokula Hazırbulunuşluk Ölçeği farklı çalışma grubunda aynı faktör yapısını sağlamakta mıdır?

> İlkokul Hazırbulunuşluk Ölçeğinden elde edilen puan ortalamaları çeşitli değişkenlerin (cinsiyet, okula başlama yaşı, okul öncesi eğitim, yerleşim yeri) alt düzeyleri açısından anlamlı farklılık göstermekte midir?

> İlkokula Hazırbulunuşluk Ölçeği ile benzer beceri ve özellikleri ölçen Metropolitan Ölçeği arasında anlamlı ilişki var mıdır? 


\section{Yöntem}

\subsection{Araştırmanın Modeli}

Araştırmanın modelini nicel araştırma yöntemlerinden tarama araştırması oluşturmaktadır. Tarama araştırmaları geniş bir kitleden çeşitli bilgiler toplanarak bir konu, fikir hakkındaki eğilimlerinin nasıl dağıldığıyla ilgilenir (Fraenkel ve Wallen, 2006). Araştırmanın ilk aşamasında daha önce psikometrik nitelikleri ortaya konan Hazırbulunuşluk ölçeğinin farklı örneklem gruplarında yapıyı koruyup korumadığına yönelik incelemelerde bulunulmuş daha sonrasında ölçek puan ortalamaları çeşitli değişkeler açısından karşılaştırılmıştır. Araştırmanın ikinci aşamasında ise Hazırbulunuşluk ölçeğinin benzer kuramsal ölçümlere sahip Metropolitan ölçeği ilişkisi test edilmiştir.

\section{2. Çalışma Grubu}

Araştırmanın ilk çalışma grubunu farklı özelliklere sahip 482 ilkokul birinci sınıf öğrencisi oluşturmaktadır. Söz konusu kişilerle Doğrulayıcı Faktör Analizi, güvenirlik analizleri ve çeşitli değişkenler açısından karşılaştırma çalışmaları yapılmıştır. Araştırmanın ikinci çalışma grubu ise 109 ilkokul öğrencisinden oluşmaktadır. Bu öğrencilerden elde edilen Hazırbulunuşluk ve Metropolitan ölçek toplam puanları karşılaştırılmıştır.

\subsection{Verilerin Analizi}

İlkokula başlayan öğrencilerin hazırbulunuşluk seviyelerinin belirlenmesi ve bu seviyelerin bazı değişkenler etrafında incelenmesi amaçlanan çalışma kapsamında elde edilen nicel veriler uygun istatistiksel teknikler kullanılarak çözümlenmiş ve elde edilen bulgular tablolar halinde sunulmuştur. Veri analiz işlemine geçilmeden önce veri dağılım yapısının incelenmesi bu dağılıma uygun olan istatistiksel işlemin doğru bir şekilde yapılması adına her değişkenin alt düzeyinde dağılımlar incelemiştir. Dağılımların normalliği hakkında birçok kanıtın bir arada sunulmasının doğru olacağı düşülmüş ve bunun sonucunda alan yazında yer alan birçok normallik test etme yollarından üçü tercih edilmiştir. İlk olarak istatistiksel bir yaklaşım sunan normallikle alakalı hipotezin test edildiği Kolmogoronov Smirnov (K-S) ve Shapiro Wilk (S-W) testi kullanılmıştır. Analiz sonucu elde edilen istatistiksel değerin anlamlı çıkması söz konusu veri dağılımın çarpık, anlamlı olmaması ise dağılımın normalliği ile alakalı kanıtlar barındırmaktadır (McKillup, 2012). Araştırmada yer alan değişkenlerin tüm alt düzeylerinin sayılarının 35'ten büyük olması sebebiyle K-S testi kullanılmıştır. Bir diğer yaklaşım olan basıklık ve çarpıklık değerlerinin $(-1,+1)$ değer aralığında yer alması da veri grubunun normal dağılım gösterdiğinin bir kanıtı olarak kabul 
edilmektedir (Büyüköztürk,2016). Normalliğin test edildiği bir diğer yöntem olan çarpıklık değerinin kendi hatasına bölünerek elde edilen istatistiğin manidarlığının test edildiği ' $Z$ testi' bu amaçla kullanılabilecek testlerden biridir. Elde edilen değerinin $\mathrm{p}$ değerinin $\alpha=.05$ için 1.96 ve $\alpha=.01$ için 2.58 ' den küçük çıkması, puanların normal dağılımdan geldiğinin kanıtı olmaktadır (Howitt ve Cramer, 2011; Field, 2009). Sözü geçen tüm kanitlar bir araya getirilerek tüm alt düzeylerde yer alan puan dağılımları incelenmiş ve karar verilmiştir. Öğrencilerin hazırbulunuşluk ölçek puanları cinsiyet, yerleşim yeri, okul öncesi eğitim alma ve yaş değişkenlere göre karşılaştırılmıştır. Her bir değişkene ait analizin belirlenmesinde, normallik testi bulguları ve değişkenin sahip olduğu alt düzey sayısı dikkate alınmıştır (Bkz. Tablo 1) Normal dağılım gösteren değişkenlere, alt düzey sayısı iki olması durumunda Bağımsız Örneklemler T Testi uygulanmıştır.

Tablo 1. Değişkenlere uygulanan istatistiksel işlemler

\begin{tabular}{lccc}
\hline Değişken & $\begin{array}{c}\text { Düzey } \\
\text { Sayısı }\end{array}$ & Dağılım & Uygulanan Testi \\
\hline Cinsiyet & 2 & Normal & $\begin{array}{c}\text { Bağımsız Örneklemler T } \\
\text { Testi }\end{array}$ \\
Yerleşim Yeri & 2 & Normal & $\begin{array}{c}\text { Bağımsız Örneklemler T } \\
\text { Testi }\end{array}$ \\
$\begin{array}{lcc}\text { Okul Öncesi Eğitim } \\
\text { Alma }\end{array}$ & 2 & Normal & $\begin{array}{c}\text { Bağımsız Örneklemler T } \\
\text { Testi }\end{array}$ \\
Yaş & 2 & Normal & Bağımsız Örneklemler T \\
& & & Testi \\
\hline
\end{tabular}

Ayrıca araştırmada kapsamında aynı amaca hizmet eden Metropolitan ölçeğinden elde edilen puanlarla Hazırbulunuşluk ölçeğinden elde edilen puanlar arasında ilişkinin varlığı test edilmiştir. İlişki için uygulanacak istatiksel yaklaşımın belirlenmesinde ölçeklerden elde edilen dağılımların normalliği test edilmiş Metropolitan ölçeğinin çarpık dağılmasından ötürü ilişki katsayısı olarak SpearmanBrown kullanılmıştır.

\section{Bulgular}

\subsection{Hazırbulunuşluk Ölçeğinin Başka Gruplara Ait Geçerlik Kanıtları}

Hazırbulunuşluk ölçeğine uygulanan DFA sonucu elde edilen uyum indeksleri ve bunlara ilişkin kararlar Tablo 2'de gösterilmiştir. 
Tablo 2. Ölçeğe ait DFA uyum indeksleri

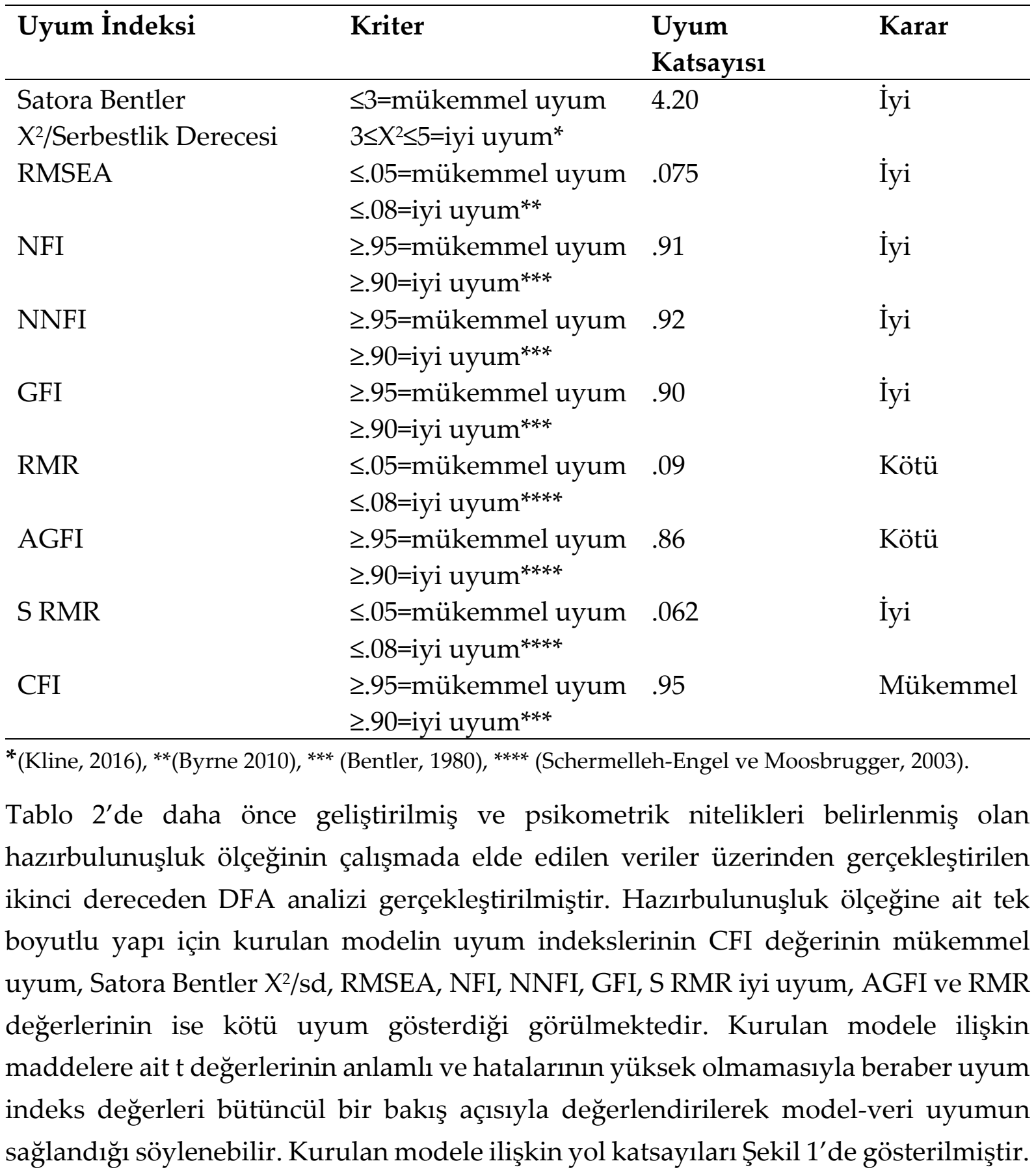




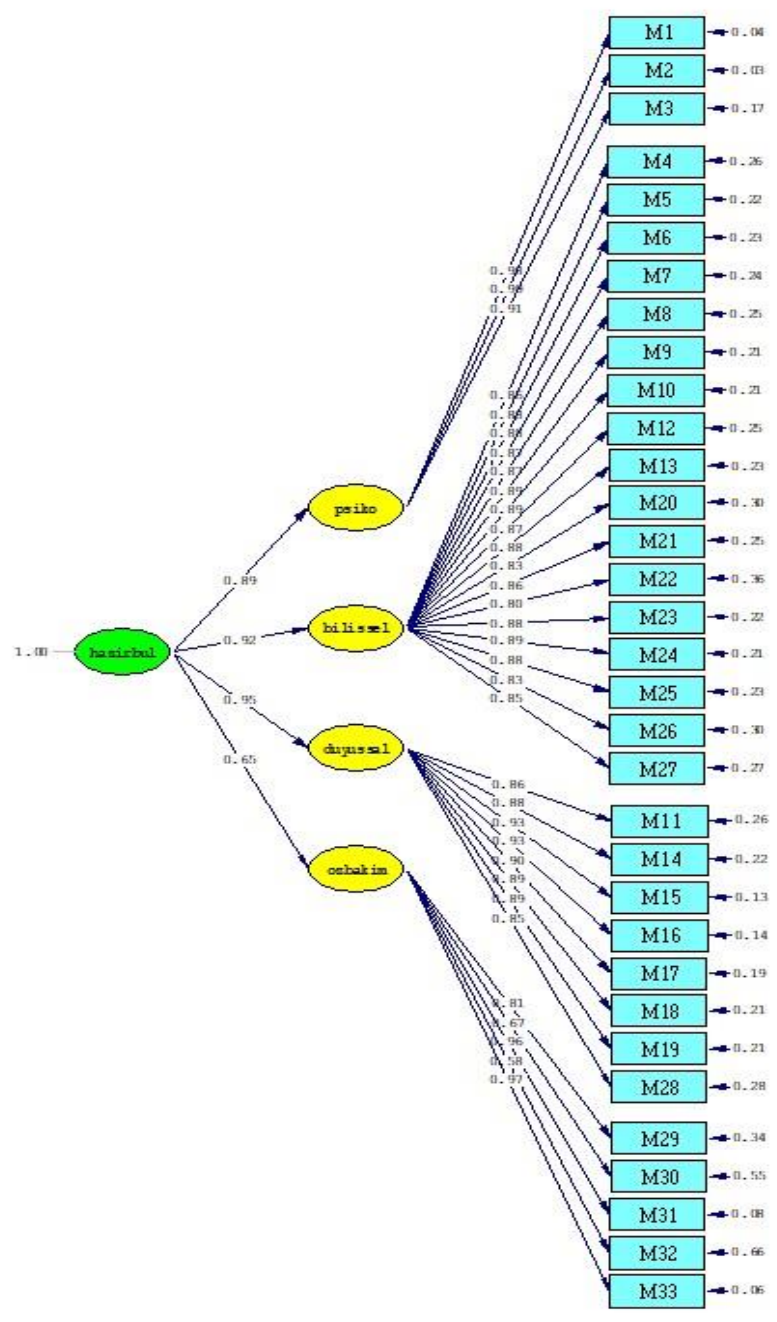

Şekil 1. Hazırbulunuşluk Ölçeğine Ait Yol Diyagramı

\subsection{Hazırbulunuşluk Ölçeğine Ait Güvenirlik Kanıtları}

Hazırbulunuşluk ölçeğinin geneline ve alt ölçeklerine ait iç tutarlılık güvenirlik katsayısı ve bileşik güvenirlik katsayısı Tablo 3’te gösterilmiştir.

Tablo 3. Hazırbulunuşluk ölçeğinden elde edilen puanlara ait Cronbach Alfa iç tutarlılık ve Bileşik Güvenirlik katsayıları

\begin{tabular}{llcc}
\hline Ölçek & Alt Ölçek & İç Tutarlılık & Bileşik Güvenirlik \\
\hline Hazırbulunuşluk & Psiko & .96 & .82 \\
Ölçeği & Bilişsel & .97 & .79 \\
& Duyuşsal & .95 & .80 \\
& Öz bakım & .89 & .71 \\
& Genel & .97 & .83 \\
\hline
\end{tabular}


Tablo 3'te hazırbulunuşluk ölçeğine ait Cronbach Alfa iç tutarlılık katsayıları incelendiğinde Psiko faktörünün .96, Bilişsel faktörünün .97, Duyuşsal faktörünün .95, Öz bakım faktörünün .89 ve ölçeğin genelinin ise .97 güvenirlik katsayısına sahip olduğu görülmektedir. Buna göre ölçeğin hem alt faktörlerinin hem tamamının iç tutarlılık anlamında güvenilir olduğu söylenebilir. Birleşik güvenirlik katsayıları incelendiğinde ise Psiko faktörünün .82, Bilişsel faktörünün .79, Duyuşsal faktörünün .80, Öz bakım faktörünün .71 ve ölçeğin genelinin ise .83 güvenirlik katsayısına sahip olduğu görülmektedir. Elde edilen sonuçlar ölçekten elde edilen puanların güvenilir olduğu göstermektedir.

\section{3. Öğrencilerin Hazırbulunuşluk Puanlarının Cinsiyet, Yerleşim Yeri, Okul Öncesi Eğitim Alma ve Yaş Durum Değişkenlerine Göre Farklılaşma Durumları}

Öğrencilerin hazırbulunuşluk puanlarının cinsiyet, yerleşim yeri, okul öncesi eğitim alma ve yaş durum değişkenlerine göre farklılaşma durumları incelemek amacıyla öncelikle dağılımın yapısı hakkında bilgi sağlamak amacıyla ölçek toplam puanlarının söz konusu değişkenlerin alt düzeylerinde gösterdikleri dağılımlar incelenmiştir. Elde edilen sonuçlar Tablo 4 'te gösterilmiştir.

Tablo 4. Hazırbulunuşluk ölçeğinin bazı değişkenlerin alt düzeylerinde gösterdiğ i dă̆ılımlara ait kanitlar

\begin{tabular}{lllllll}
\hline Değişken & Düzey & K-S & Basıklık & Çarpıklık & Z İst. & Karar \\
\hline Cinsiyet & Erkek & .200 & -.698 & -.123 & -.71 & Normal \\
& Kız & .200 & -.642 & -.103 & -.70 & Normal \\
Yerleşim Yeri & Köy & .200 & -.868 & -.101 & -.62 & Normal \\
& Merkez & .094 & -.436 & -.128 & -.83 & Normal \\
& & & & & & \\
Okul Öncesi & Evet & .062 & -.448 & -.185 & -1.20 & Normal \\
Eğitim & Hayır & .200 & -.631 & .205 & 1.25 & Normal \\
& & & & & & \\
Yaş & 66-72 ay & .200 & -.802 & -.019 & -.11 & Normal \\
& 72 ay üstü & .059 & -.519 & -.234 & -1.54 & Normal \\
\hline
\end{tabular}

Tablo 4'te Hazırbulunuşluk ölçeğinden elde edilen puanların cinsiyet, yerleşim yeri, okul öncesi eğitim alma ve yaş durum değişkenlerinin alt düzeylerinde nasıl dağıldığını incelemek adına hesaplanan Kolmogorov-Smirnov (K-S) test sonuçlarının anlamlı olmadığı, çarpıklık değerlerinin kendi standart hata değerlerine bölünerek elde edilen $Z$ istatistiğinin \pm 1.96 aralığında, basıklık ve çarpıklık değerinin \pm 1 
aralığında olduğu görülmektedir. Buna göre sözü geçen tüm değişkenlerin alt düzeylerinin normal veya normale yakın bir dağılım gösterdiği söylenebilir. Elde edilen bulgular normallik varsayımı gerektiren analizlerin yapılmasına uygun olduğunu göstermektedir. Cinsiyet, yerleşim yeri, okul öncesi eğitim alma ve yaş durum değişkenlerinde yer alan alt düzey sayısının iki olmasından ötürü grup ortalamalarını karşılaştırmak adına $\mathrm{t}$ testi uygulanmıştır. Yapılan karılaştırma testlerine ait sonuçlar Tablo 5'te gösterilmiştir.

Tablo 5. Hazırbulunuşluk ölçek puanlarının cinsiyet, yerleşim yeri, oku öncesi eğitim alma ve yaş durum değişkenlerine ait t testi sonuçları

\begin{tabular}{llllllllc}
\hline Değişken & Düzey & $\mathbf{N}$ & Ortalama & $\begin{array}{l}\text { Standart } \\
\text { Sapma }\end{array}$ & SD & $\mathbf{t}$ & $\mathbf{P}$ & $\begin{array}{c}\text { Eta- } \\
\text { Kare }\end{array}$ \\
\hline Cinsiyet & K1z & 202 & 119.65 & 26.19 & 478 & $3.79^{*}$ & .000 & .03 \\
& Erkek & 278 & 110.27 & 27.09 & & & & \\
& & & & & & & & \\
\hline Yerleşim & Köy & 229 & 114.03 & 29.47 & 480 & .14 & .885 & --- \\
Yeri & Merkez & 253 & 114.39 & 25.02 & & & & \\
& & & & & & & & \\
\hline Okul & Evet & 255 & 125.41 & 23.17 & 477 & $10.79^{*}$ & .000 & .20 \\
Öncesi & Hayır & 224 & 101.24 & 25.82 & & & & \\
Eğitim & & & & & & & & \\
Alma & & & & & & & & \\
\hline Yaş & $66-72$ ay & 222 & 114.79 & 28.51 & 480 & .42 & .670 & -- \\
& 72 ay & 260 & 113.73 & 26.07 & & & & \\
\hline
\end{tabular}

${ }^{*} \mathrm{p}<.05$ anlamlılık düzeyi kriter olarak kabul edilmiştir.

Tablo 5'e göre öğrencilerin hazırbulunuşluk ölçek puanları cinsiyete göre

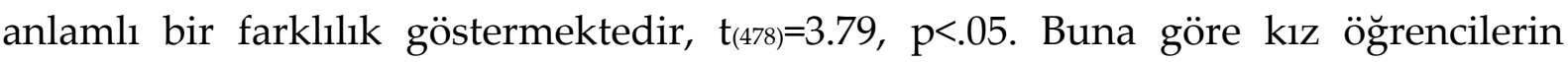
hazırbulunuşluk ölçek puanlarının (119.65) erkek öğrencilerin hazırbulunuşluk ölçek puanlarından (110.27) daha olumlu olduğu söylenebilir. Anlamlı farkın büyüklüğünün test edilmesine ilişkin hesaplanan etki büyüklüğü katsayısının ise .03 olduğu görülmektedir. Buna göre anlamlı farkın küçük etki büyüklüğüne sahip olduğu söylenebilir. Öğrencilerin hazırbulunuşluk ölçek puanları yerleşim yeri değişkeninin alt düzeylerine göre ise anlamlı bir farklılık göstermemektedir, $t_{(480)}=.14$, p>.05. Buna göre köyde yaşayan öğrencilerin hazırbulunuşluk ölçek puanları (114.03) merkezde yaşayan öğrencilerin hazırbulunuşluk ölçek puanları (114.39) arasında istatistiksel ve pratikte bir fark olmadığı söylenebilir. Bir diğer değişken olan okul 
öncesi eğitim alma değişkeninin alt düzeyleri incelendiğinde ise öğrencilerin hazırbulunuşluk ölçek puanları okul öncesi eğitim alma durum değişkeninin alt düzeylerine göre anlamlı bir farklılık göstermektedir, $\mathrm{t}_{(477)}=10.79, \mathrm{p}<.05$. Buna göre okul öncesi eğitim alan öğrencilerin hazırbulunuşluk ölçek puanları (125.41) okul öncesi eğitim almayan öğrencilerin hazırbulunuşluk ölçek puanlarından (101.24) daha fazladır. Anlamlı farkın büyüklüğünün test edilmesine ilişkin hesaplanan etki büyüklüğü katsayısının ise .20 olduğu görülmektedir. Buna göre anlamlı farkın büyük etki büyüklüğüne sahip olduğu söylenebilir. Öğrencilerin hazırbulunuşluk ölçek puanları yaş değişkeninin alt düzeylerine göre ise anlamlı bir farklılık göstermemektedir, $\mathrm{t}_{(480)}=.42, \mathrm{p}>.05$. Buna göre $66-72$ ay alt düzeyindeki öğrencilerin hazırbulunuşluk ölçek puanları (114.79) 72 ay üstü alt düzeyindeki öğrencilerin hazırbulunuşluk ölçek puanları (113.73) arasında istatistiksel ve pratikte bir fark olmadığı söylenebilir.

\subsection{Hazırbulunuşluk Ölçeğinden Elde Edilen Puanlarla Metropolitan Ölçeğinden Elde Edilen Puanlar Arasında İlişkinin İncelenmesi}

Tablo 6. Alt ölçeklerin toplam puanlarına ait normallik kanıtları

\begin{tabular}{llccccl}
\hline Ölçek & $\mathbf{N}$ & K-S & Basıklık & Çarpıklık & Z İst. & Karar \\
\hline Hazırbulunuşluk & 109 & $.200^{*}$ & -.458 & .201 & .35 & Normal \\
Metropolitan & 109 & $.106^{*}$ & .681 & -.130 & .91 & Normal
\end{tabular}

Araştırmada yer alan Hazırbulunuşluk ve Metropolitan ölçeğinden elde edilen verilerin nasıl dağıldığını incelemek adına hesaplanan Kolmogorov-Smirnov (K-S) test sonuçlarının anlamlı olmadığı, basıklık ve çarpıklık değerinin \pm 1 aralığında, Z istatistiğinin \pm 1.96 aralığında yer aldığı görülmektedir. Buna göre her iki ölçekten elde edilen toplam puanların normale yakın bir dağılım gösterdiği söylenebilir.

Araştırmada yer alan ölçeklerin normal dağılım göstermesi ve çarpık dağılıma sahip olmamasından ötürü ölçekler arasında ilişkinin belirlenmesi adına Pearson momentler çarpımı ilişki katsayısı hesaplanmıştır. Buna göre Hazırbulunuşluk ve metropolitan ölçekleri arasında anlamlı ve orta seviye $\left(\mathrm{r}_{\mathrm{mh}}=.596\right)$ bir ilişkiden söz edilebilir. Bir diğer ifadeyle Hazırbulunuşluk ölçeği arttıkça Metropolitan ölçeği puanlarının arttı̆̆ı söylenebilir.

\section{Sonuç, Tartışma ve Öneriler}

Araştırmanın sonunda daha önce psikometrik nitelikleri belirlenmiş Hazırbulunuşluk ölçeğinin farklı bir çalışma grubunda da model-veri uyumunu sağlayarak söz konusu 
yapıyı koruduğu gözlenmiştir. Ölçek için hesaplanan iç tutarlık ve bileşik güvenirlik katsayılarının ise oldukça yüksek oldukları söylenebilir. Bu bulgular Hazırbulunuşluk ölçeğinin başka gruplarda yapılacak denemelerde geçerli ve güvenilir bir ölçek olacağını ilişkin kanıtlar olarak görülmektedir. Araştırmanın bir diğer aşamasında Hazırbulunuşluk ölçeğinden elde edilen toplam puanlar çeşitli değişkenler arasında karşılaştırılmış literatürde bahsedildiği gibi cinsiyet ve okul öncesi eğitim alma değişkenlerinde anlamlı farklılar olduğu gözlenmiştir (Fidan ve Baykul, 1994). Gelişimsel açıdan erken olgunlaşan kızların erkeklere göre, okul öncesi eğitim sayesinde ön şart kazanımlarını taşıyan öğrencilerin okul öncesi eğitim almayan öğrencilere göre Hazırbulunuşluk ölçeğinden daha pozitif puanlar alması söz konusu ölçeğin bahsedilen yapıyı ölçtüğüne dair kanıtlara ek oluşturduğu söylenebilir. Araştırmanın bir diğer aşamasında ise aynı kuramsal temelini ölçmek için geliştirilen Metropolitan ve Hazırbulunuşluk ölçekleri arasındaki ilişki değerlendirilmiştir. Yapılan analizler neticesinde iki ölçek arasında oldukça iyi sayılabilecek pozitif anlamlı bir ilişki keşfedilmiştir. Bu durum hem Hazırbulunuşluk ölçeğinin güvenirliğine bir kanıt oluştururken hem de Metropolitan ölçeğine alternatif bir ölçek olabileceğine ilişkin kanıt oluşturmuştur. Ayrıca Metropolitan ölçeğinde nazaran kendi içerisinde daha az madde ile söz konusu kuramsal yapıyı ölçtüğü iddiası olan Hazırbulunuşluk ölçeği ölçme araçlarının geçerlik ve güvenirlikten sonra bir diğer özelliği olan kullanışlılık özelliğine de sahip olduğunu göstermiştir.

Ölçeğin farklı gruplarda yapısal özelliklerinin incelenmesi, çeşitli değişkenler üzerinden ortalama karşılaştırma testlerinin yapılması söz konusu ölçeğin psikometrik niteliklerini daha iyi ortaya koyma konusunda fayda sağlayacaktır. Ayrıca geliştirilen ve yapısını derinleştirilen ölçeğin okula başlama yaşındaki öğrenciler için uygulanması ve kullanılması öğrenciler için hazırlanacak eğitim ortamlarının belirlenmesinde faydalı olacaktır.

\section{Kaynakça}

Alkan, C. ve Teker, N. (1992). Programlı öğretim: Değişik teknolojiler ve Türkiye'deki uygulama. Ankara: Ankara Üniversitesi Basımevi.

Akyol, N. A. (2015). Okul öncesi eğitim kurumuna devam eden 5 yaş çocuklarının akran ilişkileri ile ilkokula hazırbulunuşluk düzeyleri arasındaki ilişkinin incelenmesi (Yayımlanmamış yüksek lisans tezi). Marmara Üniversitesi Eğitim Bilimleri Enstitüsü. İstanbul.

Başaran, İ. E. (1998). Eğitim psikolojisi (5. Bask1). Ankara: Aydan Web Tesisleri. 
Bentler, P. M. (1980). Multivariate analysis with latent variables: Causal modeling. Annual review of psychology, 31(1), 419-456.

Binbaşığlu, C. (1995). Eğitim psikolojisi (9. Bask1). Ankara: Yargıcı Matbaa.

Büyüköztürk, Ş. (2016). Sosyal bilimler için veri analizi el kitabı istatistik, araştırma deseni SPSS uygulamaları ve yorum (Genişletilmiş 22. Baskı). Ankara: PegemA Yayıncılık.

Byrne, B. M. (2010). Structural equation modeling with AMOS: Basic concepts, applications and programming. New York, NY: Taylor and Francis Group.

Çataloluk, C. (1994). Farklı sosyo-ekonomik ve kültürel ortamlarda yetişen çocukların okul olgunluğu açısından karşılaştırılması (Yayımlanmamış yüksek lisans tezi) İstanbul Üniversitesi Sosyal Bilimler Enstitüsü, İstanbul.

Çökük, K. ve Kozikoglu, I. (2020). A correlational study on primary school students' school readiness and adaptation problems. International Online Journal of Education and Teaching, 7(2), 523-535.

Dereobalı, N. (2016). Oyun temelli okuma-yazmaya hazırlık eğitimi programı'nın anaokulu çocuklarının ilkokula hazırbulunuşluk düzeylerine etkisinin incelenmesi. Elektronik Mesleki Gelişim ve Araştırmalar Dergisi, 4 (2), 78-105.

Fidan, M., Taşçi, N. ve Yılmaz, N. (2013). İlkokul birinci sınıf öğretmenlerinin 60-66 aylık öğrencilerine ilişkin görüşleri (Yayımlanmamış araştırma).

Fidan, N. ve Baykul, Y. (1994). İlköğretimde temel öğrenme ihtiyaçlarının karşılanması. Hacettepe Üniversitesi Ĕ̆itim Fakültesi Dergisi, 10 (10), 7-20.

Field, A. (2009). Discovering statistics using SPSS. London: Sage Publications Ltd.

Fraenkel, J. R. ve Wallen, N. E. (2006). How to design and evaluate research in education 2006. New York: Mc Grawall Hill.

Howitt, D. ve Cramer, D. (1997). A guide to computing statistics with SPSS for Windows. London: Simon \& Schuster, Inc.

Işıkoğlu, E. N., Ceren, Ş. Z. (2014). Birinci sınıfa başlayan çocukların, velilerin ve öğretmenlerin okula uyumlarının incelenmesi. International Journal Of New Trends in Arts, Sports E Science Education, 3 (2), 62-70.

Kapçı, E., Artar, M., Çelik, E.G., Daşc1, E. ve Avşar, V. (2013). İlkokul birinci sınıfa farklı yaşlarda başlayan çocukların ruhsal ve sosyal gelişimi ile akademik benlik algılamaları açısından karşılaştırılması. Ankara Üniversitesi Yayınlanmamış Proje. 
Karakuzu, E. ve Koçyiğit, S. (2016). Ebeveyn destekli ilkokula hazırlık programı'nın (EDİHP) okul öncesi dönem çocuklarının ilkokula hazır bulunuşluğuna etkisi. Uluslararası Erken Çocukluk Ĕ̆itimi Çalışmaları Dergisi, 1(1), 84-102.

Kerimoğlu, F. (2014). Farklı yaştaki çocukların oluşturduğu ilkokul 1. sinıflarda yaşanan sorunların belirlenmesi (Yayımlanmamış yüksek lisans tezi). Ankara Üniversitesi Eğitim Bilimleri Enstitüsü, Ankara.

Kline, R. B. (2016). Principles and Practice of Structural Equation Modeling (4 ${ }^{\text {th }}$ Ed.) New York. NY: The Guilford Press.

McKillup, S. (2012). Statistics explained: An introductory guide for life scientists (Second edition). United States: Cambridge University Press.

Senemoğlu, N. (1994). Okulöncesi eğitim programı hangi yeterlikleri kazandırmalıdır? Hacettepe Üniversitesi Ĕ̆itim Fakültesi Dergisi, 10 (10), 21-30.

Schermelleh-Engel, K., Moosbrugger, H. ve Müller, H. (2003). Evaluating the fit of structural equation models: Tests of significance and descriptive goodness-of-fit measures. Methods of psychological research online, 8(2), 23-74.

Türkyılmaz, M. İ. ve Pekdoğan, S. (2019). 6-7 yaş çocuklarda sosyal davranış ve okula hazırbulunuşluğun bazı değişkenler açısından incelenmesi. OPUS Uluslararası Toplum Araştırmaları Dergisi, 14 (20), 133-160.

Uzun, E. M. ve Alat, K. (2017). Okul öncesi dönemde uygulanan "Okula hazırız" eğitim programının ilkokul birinci sınıf öğrencilerinin hazırbulunuşluk düzeylerine etkisi. Ondokuz Mayis University Journal of Education, 36 (2), 59-80.

Ülgen, G. (1997). Ĕ̆itim psikolojisi. İstanbul: Alkım Yayınevi.

Ünver, G. B., Dikbayır, A. ve Yurdakul, B. (2015). Kesintili zorunlu eğitim ilkokul birinci sınıf uygulamalarının incelenmesi. K. Ü. Kastamonu Eğitim Dergisi, 23 (4), 1647-1664.

Yılmaz, H. ve Sünbül, A. M. (2003). Öğretimde planlama ve değerlendirme. Ankara: Mikro Yayınları. 